\title{
Vliv funkčního australského tréninku na aerobní parametry hráčů ledního hokeje
}

\section{Influence of a function „Australian“" training to fit ice hockey players}

\author{
Petr Požárek ${ }^{1}$, Jiří Suchý ${ }^{2}$ \\ ${ }^{1}$ Pedagogická fakulta, Jihočeská univerzita, České Budějovice \\ ${ }^{2}$ Fakulta tělesné výchovy a sportu, Univerzita Karlova, Praha
}

\begin{abstract}
Abstrakt
Cílem článku je charakteristika a analýza účinnosti desetitýdenního kondičního funkčního ,,australského” tréninku (dále FAT) mimo ledovou plochu. Výzkum byl realizován u profesionálních hokejistù $(n=23)$ - členů extraligového klubu HC Mountfield České Budějovice. Metoda FAT se snaží doplnit stávajíci tréninkové postupy o některé aktuálni poznatky a př́stupy ke kondičnímu tréninku v ledním hokeji. Autoři zaujímaji pozitivni stanovisko $k$ této metodě a popisují její výhody zejména ve vztahu ke snižování svalových dysbalancí a vlivu na svalovou sílu, dynamiku a vytrvalost zúčastněných probandů. FAT byl prednostně zaměren na explosivní sílu a silovou vytrvalost hlavních segmentů těla, s doplňujicími cvičeními pro stimulaci anaerobni a aerobní výkonnosti.

Pro ověreni př́nosu FAT podstoupili probandi spiroergometrické vyšetřeni na běhacím ergometru Quasar, následovalo změreni tělesného složení pomoci BIA 2000 a bioimpedančním př́istrojem Tanita. Vstupní a výstupní testováni probíhalo v neměnných laboratornich podmínkách v prostorách UK FTVS v Praze. Kvaziexperiment trval deset týdnü. Zjištěné výsledky potvrdily efektivnost tohoto tréninkového programu v podobě zvýšení aerobní zdatnosti, která vykazovala u vstupního testování středovou hodnotu $V_{2 \max } 55,89 \mathrm{ml} . \mathrm{kg} . \mathrm{min}^{-1}$. Při výstupním testování jsme dosáhli stredové hodnoty $\mathrm{VO}_{2 \max } 58,67 \mathrm{ml} . \mathrm{kg} . \mathrm{min}^{-1}$.
\end{abstract}

\begin{abstract}
:
The aim of the case study is to analyse the effects of a 10-week fitness Function Australian Training (FAT) off-ice. The research was conducted with 23 professional ice hockey players $(n=23]$, members of the ice hockey league club HC Mountfield České Budějovice. The FAT method strives to complement existing training methods of selected current knowledge and approaches to ice hockey fitness training. The authors express a positive opinion on this method and describe its advantages especially in relation to reducing muscle imbalances and effect on muscle strength, dynamics and persistence of participating probands. The FAT was primarily focused on explosive strength and power endurance of main body segments with additional exercises to stimulate anaerobic and aerobic performance. The probands underwent a spiroergometric testing on the Quasar running ergometer, followed by measurement of body composition using BIA 2000 and another testing on the bioimpedance device Tanita in order to verify the contribution of FAT. The input and output testing proceeded under laboratory constant conditions on the premises of the UK FTVS in Prague. The quasi experiment lasted for ten weeks. The obtained results confirmed the effectiveness of this training programme by increasing aerobic performance, which has proven the average value of $\mathrm{VO}_{2 \max } 55,89 \mathrm{ml} . \mathrm{kg} . \mathrm{min}^{-1}$ at the input testing. The output testing has showed the averagevalue of $\mathrm{VO}_{2 \max } 58,67 \mathrm{ml} . \mathrm{kg} \cdot \mathrm{min}^{-1}$.
\end{abstract}

Kličcová slova: hokej, testování, trénink, kondiční trénink, funkční trénink

Key words: ice hockey, testing, training, conditioning trainig, functional training 


\section{ÚVOD}

Lední hokej patří do skupiny fyzicky velmi náročných sportů. Moderní lední hokej je komplex, ve kterém se souběžně zvyšují požadavky na kondiční předpoklady hráče i jeho herní techniku. Obojí se odráží v úrovni taktického myšlení a jednání. Z fyziologického hlediska představuje intervalový a přerušovaný typ aktivity vysokou úroveň celkové tělesné zdatnosti, široké spektrum motorických dovedností, reakčních a rozhodovacích schopností (Heller, 2005).

Kostka et al. (1986) uvádějí, že je nezbytné zapojovat do tréninkového procesu v ledním hokeji také tréninkové jednotky mimo led s cílem stimulovat bioenergetické zásoby, dále aktivaci jednotlivých svalových struktur a regenerační procesy prostřednictvím kompenzací jednostranného zatížení.

Quinneyho (2008) longitudinální studie poukazuje na zvyšování nároků na tělesnou výkonnost hokejisty v utkání, zvláště pak na maximální anaerobní výkon hráčủ kanadsko-americké Národní hokejové ligy (NHL).

Při náhlých změnách směru bruslení se zapojují také adduktory a abduktory kyčelních kloubů, které čelí účinkům dostředivé síly (Cady-Stenlund, 1998). Důležitost svalové síly poukazuje nález největších rozdílů v silových parametrech ze všech sledovaných funkčních parametrů, a to mezi elitními a juniorskými hokejisty (Hoff et al., 2005).

Vysoký stupeň rozvoje kondičních a koordinačních schopností umožňuje využívat racionální technickou dovednost, efektivní taktické myšlení se zapojením osobních předpokladů hráče (Laczo, 2009; Tóth, 2010). Individuální herní výkon hráče se skládá z krátkých opakovaných intenzivních pohybů. Veillette (2008) uvádí, že hráč se dostane na ledovou plochu $17 x$ za celý zápas. Přitom čas strávený na ledové ploše je $85 \mathrm{~s}, \mathrm{z}$ toho je $40 \mathrm{~s}$ v zatížení (maximálním a středním) a $45 \mathrm{~s}$ bez zatížení po přerušení hry. Proto je potřeba se zaměřit na pohybové schopnosti skládající se z rychlostně-silových schopností s důrazem na koordinační pohyb.

Pro stabilizaci bederní páteře je velmi důležité, aby se správně zapojoval hluboký stabilizační systém páteře během pohybu (HSSP), tedy je nutné, aby byly dostatečně silné břišní svaly, které pak tvoří př́ední oporu. Bederní páteř se tak zpevňuje a snižuje se vliv vnější zátěže (Malátová-Rokytová, 2007; Malátová, 2007; Malátová-Dřevikovská, 2010).

Statická síla trupu a dalších segmentů těla má význam při kontaktu se soupeřem, pro udržení rovnováhy a efektivní přenos sil při bruslení a manipulaci s holí. Při bruslení se uplatňuje dynamická síla extenzorů kyčle, extenzorů kolenního kloubu a lýtkových svalů (Brocherie et al., 2005; Manners, 2004).

Michalov, Sližík a Švenda (2012) uvádí, že jedním z důležitých prvků v přípravném období je snaha aplikovat bojové sporty do jedné tréninkové jednotky týdně. My jsme zvolili prvky z karate a boxu. Hráči ledního hokeje se naučí harmonicky dýchat a zároveň zefektivní využití energetického potenciálu svého těla.

Perič a Dovalil (2010) považují prŕípravné období za nejdelší období a pro svoji charakteristiku i za nejdůležitější období v ročním tréninkovém cyklu (RTC). Tréninkové jednotky v průběhu přípravného období mění svou charakteristiku. Především blížícím se koncem př́ípravného období se přechází na specializovaný typ tréninku (specifické cvičení) a trénink nabývá syntetického charakteru. Je poněkud složitější než přistup analytický.

Bahenský (2012) poukazuje na efektivnější tréninkové metody v prŕípravném období, kdy je na vše dostatek času, protože během závodního období dochází k přechodu tréninkových jednotek na individuální přístup tzv. na tělo.

V závodním období by měl být sportovec připraven nejen fyzicky, ale především psychicky na podání svého maximálního výkonu. Sportovec by měl být „zdravě“ motivovaný (Navarro, 2001).

Funkční australský trénink (dále jen FAT) je novým tréninkovým programem, který vychází z kombinace nových i již prověřených tréninkových metod využívajících širokou škálu pomůcek, vlastní váhu těla a cvičení ve skupinách. Dříve se preferoval analogický typ tréninku, který byl prezentován tréninkovými jednotkami v podobě opakujícího se stereotypu - ranní tréninková jednotka v posilovně, odpolední tréninková jednotka na bicyklu. Základní volbou tohoto tréninku bylo odděleně a co největším objemem posílit jednotlivé partie. Z tohoto pohledu považujeme tuto formu tréninku za překonanou, protože neodpovídá současným požadavkům a nárokům na fyzickou připravenost (Hoff et al., 2005). Domníváme se, že toto tvrzení je aktuálním problémem prolínání se starší a mladší generace u vrcholového sportu. Vzhledem k typickému přetěžování pohybového aparátu u ledního hokeje bylo naším cílem ukázat, že FAT nemá vedlejší účinky na prohlubování svalové nerovnováhy u jednotlivých segmentů těla (trup, dolní a horní končetiny).

Základní filosofií FAT je nikoliv izolace jednotlivých svalů, s nížjsme se u probandů setkali v předešlé přípravě, ale naopak společné zapojení velkého počtu svalových partií horní a dolní poloviny těla, procvičení celého těla 
zcela odlišným způsobem. Aktuální metody FAT se zaměřují na explozivní sílu, rychlostní silovou vytrvalost hlavních segmentů těla s doplňujícími cvičeními pro stimulaci koordinace, anaerobní a aerobní výkonnosti. Pro ověření předpokládané efektivity a vhodnosti jsme zrealizovali tuto studii.

Tréninková jednotka se zapojením FAT je v úvodní části zaměřena na zahřátí organismu, aktivaci kloubního aparátu, aplikaci dynamického strečinku a př́pravu organizmu na hlavní tréninkovou jednotku. Až do této fáze se jedná o shodu se standardním tréninkovým postupem. Hlavní část se poté zaměřuje na posílení hlubokého stabilizačního systému. Zároveň je snahou v maximální možné míře přenášet hokejové prvky do př́pravy mimo ledovou plochu, kde se zaměřujeme na balanční cvičení v kombinaci s prvky podporujícími explozivní sílu a rychlostně silovou vytrvalost.

\section{CÍL}

V rámci př́ípravy tohoto článku jsme vytyčili následující cíle:

1. teoretická rešerše relevantních poznatků, charakteristika FAT,

2. posouzení účinnosti aplikovaného tréninku FAT na aerobní parametry prostřednictvím zjištění $\mathrm{VO}_{2 \max }$,

3. vyrovnání svalových dysbalancí spojené s hypertrofií deficitních svalových skupin.

\section{METODIKA}

Testovanými probandy byli hokejisté HC Mountfield České Budějovice hrající Českou extraligu, nejvyšší domácí soutěž, kde se v sezóně 2011-12 umístili po základní části na pátém místě. Po skončení této sezóny došlo ke změně ve složení družstva. Klub změnil na sezónu 2012-13 náhled na současné tréninkové metody. Kvaziexperiment byl realizován po deset týdenních mikrocyklů (23. 4.-26. 6. 2012). Výzkumný soubor tvořilo 23 probandů ve věku 24,6 \pm 6,19 let, průměrná tělesná výška $183,4 \pm 4,38 \mathrm{~cm}$ a průměrná tělesná hmotnost $86,2 \pm 8,22 \mathrm{~kg}$. Vstupní a výstupní testování proběhlo na běhacím ergometru. Chyba měření u této metodiky dosahuje podle Bunce (1999) $2 \%$.

Jednalo se o jednoskupinový postupný kvaziexperiment, ve kterém se testovaný soubor podrobil čtyřtýdennímu mikrocyklu věnovanému rozvoji všeobecné vytrvalosti a síly, dvoutýdennímu mikrocyklu se zaměřením na rychlostně-silové schopností, dvoutýdennímu mikrocyklu, který zlepšoval rozvoj koordinačněrychlostních schopností. Poslední dva mikrocykly byly zaměřeny na maximální silově-rychlostní schopnosti.

$\mathrm{K}$ měření maximální aerobní kapacity $\mathrm{VO}_{2 \max }$ jsme využili běhací koberec s protokolem dle Bunce (1999). Měřní svalové hmoty probíhalo za pomoci dvou přístrojů BIA 2000 a bioimpedančního přístroje Tanita. Dva různé přístroje zajišt’ovaly objektivnost výsledků. Měření bioimpedance probíhalo ve shodných termínech jako testování na běžíím koberci.

Probandi souhlasili s experimentem a podepsali prripravený formulár. S výzkumem vyslovila souhlas i etická komise klubu HC Mountfield složena z týmových doktorů. Vstupní a výstupní parametry byly statisticky vyhodnoceny v programu Microsoft Excel 2003 a podrobeny Studentovu t-testu.

\section{VÝSLEDKY}

Výše uvedené poznatky v teoretické části článku jsme se snažili zahrnout do tréninkového procesu FAT. Tyto informace doplňujeme o krátkodobé cíle získané ze studie literatury uváděné v teorii a praktických poznatcích. Snažili jsme se narušit stereotypy předešlých RTC. Hráči tento trénink využívají v přípravném a v soutěžním období. Při sledu tří zápasů v mikrocyklu dochází u hráčů k poklesu trénovanosti a prohlubování svalových dysbalancí. FAT se dva dny před zápasem zaměřuje na zvýšení zátěže, které se skládá ze silově-rychlostních cvičení. Cílem je dynamické provedení cviku se zaměřením na správnou techniku. Hráči pracují se $40 \%$ zátěží svého osobního maxima. Počet opakování je stanoven individuálně (12-16 opakování). Počty sérí jsou vždy tř̌i - první na zapracování techniky správného provedení, další dvě jsou součástí tréninkového programu. Doba této tréninkové jednotky dosahuje 40-50 minut. Den před zápasem se zapojují prvky balančního tréninku se zapojením hlubokého stabilizačního systému. Hráči využívají nestabilní plochy v podobě bosu míčủ, trampolín, to vše je doplněno o odrazové průpravné cviky simulující hokejový odraz na ledě, stř̌elu a přihrávku. Všechny tyto prvky se provádějí i na druhou stranu, protože hokej je sportem, který organismus jednostranně přetěžuje. Tréninková jednotka tohoto charakteru trvá 35 minut. V den zápasu jde především o koordinačně-rychlostní cviky, které jsou zaměřené na využívání nízkých a středních překážek, bosu míčủ a trampolín. Po každém cviku 
následuje 3-5m sprint. Tento trénink má časovou dotaci 20 minut. Den po zápase se využívá kompenzační trénink, který je koncipován na trríčlenné skupinky, aby byla zachována kvalita prováděných cviků se zpětnou opravnou vazbou u jednotlivých hráčů. Doba trvání je 15 minut.

U vstupního testování bylo dosaženo středové hodnoty $\mathrm{VO}_{2 \max } 55,89 \mathrm{ml} . \mathrm{kg}$.min ${ }^{-1}$. Při výstupním testování jsme dosáhli středové hodnoty $\mathrm{VO}_{2 \max } 58,67 \mathrm{ml} \cdot \mathrm{kg} \cdot \mathrm{min}^{-1}$. (Tabulka 1). Čtyři probandi dosáhli zlepšení nad $10 \%$ $\mathrm{VO}_{2 \max }(\mathrm{P}<0,00046)$. Sedm probandů zvýšilo své výsledky o $5 \%(\mathrm{P}<0,0056)$. Čtyři hráči dosáhli zlepšení o 3 \% ( $\mathrm{P}<0,0032)$. Čtyři probandi stagnovali a stejný počet probandů se zhoršil, protože se během př́pravy zranili a jejich návrat do tréninkového procesu byl v týdnu, kdy proběhlo výstupní testování. Nejvýraznějšího zlepšení dosáhl hráč, kterému se změny z laboratorního testování projevily v praxi a v průběhu sezóny nastupoval v první a druhé sestavě (do zápasu nastupují čtyři pětičlenné sestavy).

Při průměrném hodnocení výsledků jsme došli k závěru, že se nám podařilo navýšit svalovou hmotu trupu z 36,6 kg na 37,8 kg. Pravou horní končetinu jsme zlepšili a vyšly nám statisticky významné hodnoty $(\mathrm{P}<$ 0,005 , Tabulka 3). Levou horní končetinu jsme zlepšili a statisticky významné hodnoty nám vykázaly $\mathrm{P}<=0,02$ (Tabulka 4). U pravé dolní končetiny jsme zaznamenali zlepšení, ale nedošlo ke staticky významnému zlepšení (Tabulka 6). Ke stejným výsledkům jsme došli i u dolní levé končetiny (Tabulka 7).

Tabulka 1: Vstupni a výstupni výsledky maximální aerobni kapacity - VO2max hráčů HC Mountfield ČB $s$ dvouvýběrovým párovým t-testem na střední hodnotu

\begin{tabular}{|l|r|r|}
\hline & \multicolumn{1}{c}{ Vstupní } & \multicolumn{1}{c|}{ Výstupní } \\
\hline Průměr & 55,89 & 58,67 \\
\hline T & 0,00046 & \\
\hline
\end{tabular}

Tabulka 2: Vstupní a výstupní testování (kg) pomocí př́stroje Tanita-horních končetin (HK), trupu a dolnich končetin (DK).

\begin{tabular}{|c|c|c|c|c|c|}
\hline \multicolumn{1}{|c|}{} & \multicolumn{5}{|c|}{ testování(kg) } \\
\cline { 2 - 7 } & HK & HK & TRUP & DK & DK \\
\cline { 2 - 6 } & pravá & levá & & pravá & levá \\
\hline VSTUPNÍ & 4,4 & 4,4 & 36,6 & 11,7 & 11,6 \\
\hline VSTUPNÍ & 4,6 & 4,6 & 37,8 & 12 & 12 \\
\hline
\end{tabular}

Tabulka 3: Dvouvýběrový párový t-test na střední hodnotu HKP: horní končetina, pravá

\begin{tabular}{|l|r|r|}
\hline & \multicolumn{2}{c|}{ Vstupní } \\
\hline Průměr & 4,45 & 4,58 \\
\hline $\mathrm{T}$ & 0,005076 & \\
\hline
\end{tabular}

Tabulka 4: Dvouvýběrový párový t-test na střední hodnotu HKL: horni končetina, levá

\begin{tabular}{|l|r|r|}
\hline \multicolumn{2}{|c|}{ Vstupní } & \multicolumn{2}{c|}{ Výstupní } \\
\hline Průměr & 4,45 & 4,58 \\
\hline $\mathrm{T}$ & 0,020421 & \\
\hline
\end{tabular}


Tabulka 5: Dvouvýběrový párový t-test na střední hodnotu trupu

\begin{tabular}{|l|r|r|}
\hline & \multicolumn{1}{|l|}{ Vstupní } & \multicolumn{1}{l|}{ Výstupní } \\
\hline Průměr & 36,63 & 37,77 \\
\hline $\mathrm{T}$ & 0,00059 & \\
\hline
\end{tabular}

Tabulka 6: Dvouvýběrový párový t-test na střední hodnotu DKP: dolní končetina, pravá

\begin{tabular}{|l|r|r|}
\hline & \multicolumn{1}{|l|}{ Vstupní } & \multicolumn{1}{l|}{ Výstupní } \\
\hline Průměr & 11,72 & 12,03 \\
\hline T & $7,54 \mathrm{E}-05$ & \\
\hline
\end{tabular}

Tabulka 7: Dvouvýběrový párový t-test na střední hodnotu DKL: dolni končetina, levá

\begin{tabular}{|l|r|r|}
\hline \multicolumn{2}{|c|}{ Vstupní } & \multicolumn{1}{c|}{ Výstupní } \\
\hline Průměr & 11,64 & 11,95 \\
\hline $\mathrm{T}$ & $7,76 \mathrm{E}-05$ & \\
\hline
\end{tabular}

\section{DISKUSE}

Z hlediska správné kompenzace přetěžovaných svalových skupin je FAT vhodnější než analogické posilování, protože dochází $\mathrm{k}$ upevnění pohybu v šikmých řetězcích. Tím zvýšíme efektivitu spolupráce jednotlivých svalových skupin, jak uvádí Hoff (2005). Tato zjištění jsme v rámci našeho kvaziexperimentu potvrdili. Trénink je zároveň vhodné koncipovat k posílení jednotlivých antagonistických dvojic, čímž zajistíme nejenom zvýšený nárok na kardiovaskulární soustavu a předejdeme jednostrannému zatížení organismu, ale zejména upevníme koordinaci celého těla a jeho orientaci v prostoru. To vše za použití adekvátní zátěže, čímž je splněn nárok na zvýšení síly při sportovním výkonu. Činnost probíhá za vysoké tepové frekvence, což má za následek adaptaci těla na tento typ zatížení.

Jednou z dalších výhod oproti silovému tréninku v posilovně je snížený nárok na kloubní aparát - nedochází k přetěžování kloubů, vazů a šlach kvůli mnohdy samoúčelnému zvedání vah. Tuto metodiku jako první prezentuje Navarra (2001).

Dalším ze subjektivně sledovaných pozitiv, která přinesl náš konkrétní výzkum, je oživení a nabourání stereotypních př́ipravných cyklů, které mnohdy vedly k obecné demotivaci hráčů. FAT za použití nejrůznějšího vybavení (gumy GUN-eX, šlapací stroj Kranking, medicinbaly, švihadla, TRX, bosu, CrossCore, overbally, gymbally, gumičky, aquahity, činky, trampolíny, flowiny a fit boxy) a současně se zařazením prvků ze sportovních her, plavání, gymnastiky a atletiky přináší zajímavější a efektivnější způsob tréninku. U jednotlivých hráčů jde o spouštěcí prvek nové motivace ke kvalitní fyzické prrípravě. Naše aerobní laboratorní výsledky na běžícím koberci ukazují pozitivní vliv tohoto tréninku na výsledky VO2max.

Podle našeho názoru lze FAT doporučit hráčům ledního hokeje, kteří od svého tréninkového úsilí očekávají správně rozvinuté, koordinované tělo bez zbytečného zatížení opěrného aparátu. Domníváme se, že modifikovaný trénink je vhodný také pro hráče $\mathrm{v}$ rehabilitačním režimu, protože použitá široká škála pomůcek a metod reflektuje zdravé posilování z hlediska fyzioterapie. FAT potvrzuje již zaběhnutá pravidla tréninkového procesu u publikovaných autorů a svým novým pojetím apeluje na účelné, odborné a zdravé trénování.

Ve srovnání s jinými sporty jsou nároky na aerobní výkon v ledním hokeji spíše střední, současní elitní hokejisté dosahují maximální spotřeby kyslíku 55-59 ml.kg.min-1. na bicyklovém spiroergometru (Vescovi, Murray \& Van Brest, 2006; Montgomery, 2006). Naše studie testovala hráče hokeje na běžíím ergometru, kde sledovaní dosáhli zlepšení po desetitýdenním tréninkovém programu z 55,89 na 58,67 ml.kg.min-1 (Tabulka 1). Sledovaní probandi dosahují hodnot maximální spotřeby kyslíku v horním pásmu uváděném v literatuře.

Ve své studii spatřujeme některé nedostatky, které jsme zjistili v průběhu aplikace FAT a při vyhodnocování výsledků. Nedostatky bereme jako impuls do další práce. V dalším výzkumu bychom se rádi zaměřili na lateralitu probandů a zkusili vytvořit kontrolní a experimentální skupinu. U profesionálních týmů jde toto rozdělení velice těžko, protože vedení klubů nechce přistoupit na experiment, který by mohl ohrozit výkonnost v soutěži. 
Studie Vanderky \& Kabáta (2012) poukazuje na současné zvýšení nároků na pohybové schopnosti a zručnosti jednotlivých hráčů ledního hokeje. Tím potvrzují naší studii, která vyzdvihuje funkčnost tohoto tréninkového programu, jenž proběhl v souladu s metodikou. Neprohloubil svalové dysbalance a transferoval výsledky do herní činnosti jednotlivce v soutěžním období.

\section{ZÁVĚRY}

Navržený trénink způsobil zlepšení aerobní výkonnosti až o $21 \% \mathrm{VO}_{2 \max }$. Zaznamenali jsme statisticky významný rozdíl větší než 0,01 .

Z toho vyplývá, že cíle byly dosaženy. Charakterizovali jsme nový tréninkový program Funkční australský trénink. U patnácti probandů se po jeho absolvování zlepšily kondiční předpoklady o nejméně $3 \%$, udávané (Bunc, 1999) jako hranice označující zlepšení kondice. Výsledky poukazují na nárůst svalové hmoty v oblasti trupu i horních a dolních končetin. Zároveň bylo docíleno vyrovnání svalových dysbalancí.

\section{LITERATURA}

Bahenský, P. (2012). Vývoj sportovního tréninku v běhu na 1500 m. Studia Kinanthropologica, XIII, (2), 108125

Brocherie, F., Babault, N., Cometti, G., Maffiuletti, N., \& Chatard, J. C. (2005). Electrostimulation training effects on the physical performance of ice hockey players. Medicine \& Science in Sports \& Exercise, 37 (3), p. $455-460$

Bunc, V. (1990). Biokybernetický př́stup k hodnocení reakce organismu na tělesné zatižení. Praha: VÚT UK FTVS, 1990

Bunc, V. (1994). A simple method for estimation aerobic fitness. Ergonomics, 37, p. 159-165

Bunc, V. (1999). Changes of ventilator threshold and energy cost of running in soccer players duty in the training. J. Sports Sci. vol. 17, No 7, p. 567-568.

Cady, S. \& Stenlund, V. (1998). High performance skating for ice hockey. Champaign, IL: Human Kinetics. Heller, J. (2005). Laboratory Manual for Human and Exercise Physiology. Prague, Charles University, s. 186. Hoff, J., Kemi, O. J. \& Helgerud, J. (2005). Strength and endurance differencies between elite and junior elite ice hockey players. International Journal of Sports Medicine, 26(7), p. 537-541

Laczo, E. (2009). Obsahové zameranie letnej kondičnej prípravy v l’adovom hokeji. In Telesná výchova a šport Vol. 19, No. 2, p. 22-25. ISSN 1335-2245

Malátová, R. \& Dřevikovská, P. (2010). Test sed-leh opakovaně z testové baterie UNIFITTEST a Brániční test v tělovýchovné praxi. Studia Kinanthropologica. 11(1):24-29.

Malátová, R. \& Rokytová, J. (2007). Význam hlubokého stabilizačního systému v oblasti vertebrogenních obtíží. Studia Kinanthropologica, 7(1), 17-22.

Malátová, R. (2007). Význam hlubokého stabilizačního systému páteře. Studia Kinanthropologica, 7(2), 89-96. Michalov, L., Sližík, M. \& Švenda, D. (2012). Zdravotně výchovné aspekty v bojových uměních. Studia Kinanthropologica, (Vol. 13, 2, pp 92 - 100). České Budějovice: Jihočeská univerzita, Pedagogická fakulta. ISSN - 1213-2101.

Manners, T. W. (2004). Sport-specific training for ice hockey. Strenght \& Conditioning Journal, 26(2), p. 16-21. Martens, R. (1990). Successful Coaching. Human Kinetics, Champaign, IL.

Montgomery, D. L. (2006). Physiological profile of professional hockey players; a longitudinal study. Aplied Physiology, Nutrition and Metabolism, 31, p. 181-185

Navarro, V. F. (2001). Planificacion y control del entrenamiento en natacion. Madrid: Tapa blanda.

Perič, T. \& Dovalil, J. (2010). Sportovni trénink. Praha: Grada,160 s.

Quinney, H, A., Dewart, R., Game, A., Snydmiller, G., Warburton, D. \& Gordon, B. (2008). A 26 year physiological description of a National Hockey League team. Applied Physiology. Nutrition and Metabolism, 33, p. $753-760$

Seliger, V. (1971). Energetický výdaj u hráčů ledního hokeje. Teorie a praxe tělesné výchovy, 19(7), 427-431. Tóth, I., Hamar, D., Gregor, T. a kol. (2010). L'adový hokej. 1. vydanie, TO-MI Ice Hockey Agency, 392 s. Vanderka. M. \& Kabát, M. (2012). Effects of combined strenght on changes in speed-strenght performance in young hockey players, Studia sportiva, č. 2, s. 46 - 53, Kineziologická sekce, 2012 
Veillete, R. (2008). Physical development for jockey. (On-line) Université Laval: Quebec City, Canada Vescovi, J. D., Murray, T. M. \& Van Heest, J. L. (2006). Position performance profilig of elite ice hockey players. International Journal of Sports Physiology and Performance, 1, p. 84-94. 